\title{
Conceptualization of CONTAINMENT in Chinese
}

\author{
A corpus-based study of the Chinese space \\ particles $l i$, nèi, and $z h \bar{n} n g$ \\ [中文容納語意認知：以語料庫方法研究中文 \\ 空間詞「裡」、「內」、「中」]
}

Hung-Kuan Su [蘇洪寬] and Alvin Cheng-Hsien Chen [陳正賢]

National Taiwan Normal University [國立台灣師範大學]

This study investigates the semantic variations of three near-synonymous space particle constructions of CONTAINMENT in Chinese: [zài NP lǐ/nèi/ zhōng]. While previous work has mostly applied qualitative analyses of the semantic differences between these particles, this study presents a corpusbased analysis examining the relationship between space particles and their co-occurring landmarks in the locative construction. Two quantitative analyses were conducted: a multiple distinctive collexeme analysis and a post-hoc semantic analysis. Our results suggest the following. First, $l_{l}$ is a more unmarked particle in encoding CONTAINMENT, co-occurring with both canonical landmarks and a wider range of entities. Second, nèi shows a strong preference for landmarks denoting temporal concepts; this metaphorical use often implies a preplanned objective in the proposition, with the landmark as an intended deadline. Finally, zhōng shows a strong connection to landmarks denoting high-dynamicity events. This extended use often comes with a marked aspectual reading of the landmark.

Keywords: cognitive semantics, quantitative corpus linguistics, space particles, containment, collostructional analysis, distinctive collexeme

關鍵詞：認知語意學、量化語料庫語言學、空間詞、容納概念、 搭配構式分析法、區辨共現詞 


\section{Introduction}

Space conceptualization is of central concern in cognitive semantics (Svorou 1994, Sandra \& Rice 1995, Boers 1996, Tyler \& Evans 2001, 2003, Pollio et al. 2005, Lindstromberg 2010). Cross-linguistically, spatial relations are often encoded by a closed set of spatial terms. The semantics of these spatial terms can be broken down into primitives, such as concepts of proximity, contiguity, and containment, and are thus topological in nature (Miller \& Johnson-Laird 1976, Jackendoff 1983, Levinson et al. 2003). In particular, this study focuses on how Chinese speakers conceptualize the CONTAINMENT relation through three near-synonymous space particle constructions [zài NP lì/nèi/zhōng].

In Chinese, the concept of CONTAINMENT can be encoded by more than one space particle, including $l \grave{l}$, nèi, and zhōng, as exemplified in (1). While these particles are often treated as almost synonymous, it would be interesting to see how they differ in language use, as truly synonymous patterns in language are rare (Liu 2010). Several studies have tried to account for the semantic differences of these three space particles through surveying of their potential grammatical patterns (Xing 1996, Zeng 2005, Yang 2008, Zhang \& Liu 2008) (cf. Section 2.2 for a comprehensive review). However, most previous analyses have been qualitative and descriptive in nature. In contrast, this study aims to investigate these conceptually similar particles from a quantitative corpus-based perspective.

$(1)^{1}$ a. Zài wèilái wǔ nián nèi zēngjiā dào shíyì rénkǒu.

ZAI future five year NEI increase to billion population

'(It) increases to 1 billion people in the upcoming five years.'

b. Zài guòqù de yì nián zhōng xîlāruî fāxiàn le tā nèizài de ZAI past DE one year ZHONG Hillary discover PFv her inner DE liliàng. strength

'In the past year, Hillary discovered her inner strength.'

c. Zài guòqù de liù nián lǐ bàn zhe wǒmen chéngzhăng de

ZAI past DE six year LI accompany IPFV we grow DE mǔxiào.

alma.mater

'The alma mater, which accompanied us as we grew over the past six years.'

1. The word segmentation in each example is based on the original corpus provider. The meanings of the abbreviations used in the inter-glossing are given in the appendix. The target words under investigation (i.e., zài, lì, nèi, and zhōng) are capitalized in the second line without glossing. 
A spatial scene encoded by a space particle can often be graphically represented by an image schema (Johnson 1987), denoting the spatial relation of a conceptually more salient object in opposition to a background entity. The former is often referred to as the "figure" or "trajector" in cognitive semantics, the latter as the "ground" or "landmark." This study will adopt the dichotomous terms "trajector" (TR) and "landmark" (LM) for consistency. We hope to reveal subtle semantic differences between these three similar particles by examining their frequently cooccurring LMs in the space particle construction [zài NP lǐ/nèi/zhōng]. Additionally, their semantic preferences may shed further light on the conceptualization of Chinese ContaInMENT image schema.

\section{Literature review}

\subsection{A usage-based constructionist approach to grammar}

The present study adopts a usage-based approach to grammar (Croft \& Cruse 2004:291-327, Gries \& Ellis 2015), which features the central hypothesis that grammatical patterns are symbolic units arising from conventional routines, whose structural and semantic characteristics greatly reflect our cognitive understanding (Langacker 1997) and interactional considerations (Ono \& Thompson 1996, Thompson \& Couper-Kuhlen 2005). Our mental grammar can be interpreted as "a structured inventory of conventional linguistic units" (Langacker 1991b:511). In other words, language use showcases our cognitive understanding of the world (Lakoff \& Johnson 1980, Lakoff 1993, Croft 2001, Tyler \& Evans 2003). Therefore, an empirical study of how a grammatical structure is used is an effective way to account for its central semantics and functions. This symbolic view of grammar, which has also been commonly referred to as construction grammar (Croft 2001, Tomasello 2003, Goldberg 2006), foregrounds the importance of repeated language experiences in the shaping and entrenchment of language knowledge.

Following this usage-based and constructionist approach to linguistic structures, the study of constructional meanings often boils down to a critical analysis of the co-occurrence of grammatical patterns of varying schematicity (e.g., words, partially schematic patterns, or fully schematic constructions) (Hunston \& Francis 2000, Goldberg 2006, Gries \& Ellis 2015). As distributional cooccurrences receive more attention in the research paradigm of usage-based grammar, studies of construction grammar or of cognitive linguistics in general have witnessed "a quantitative turn" in recent years (Janda 2013:1). In particular, Collostructional Analysis (CA), first proposed by Stefanowitsch \& Gries (2003), 
has now become a major methodological framework for constructionist linguists to study the functional coherence of particular schematic constructions (Stefanowitsch \& Gries 2003, 2005) and the functional differences among semantically similar constructional alternatives (Gries \& Stefanowitsch 2004b).

Table 1. Collostructional analysis framework

\begin{tabular}{ll}
\hline Sub-analyses & Objective \\
\hline Collexeme (Stefanowitsch \& & $\begin{array}{l}\text { To examine the association of a word and a particular slot of a } \\
\text { schematic construction }\end{array}$ \\
Gries 2003) & $\begin{array}{l}\text { To examine the association of a word pair in two slots of a } \\
\text { schematic construction }\end{array}$ \\
Covarying Collexeme & To examine a distinctive word that effectively differentiates two \\
Distinctive Collexeme (Gries \& & near-synonymous schematic constructions \\
Stefanowitsch 2004b) &
\end{tabular}

CA refers to a series of corpus-based analyses of the lexical realizations of schematic grammatical templates, as summarized in Table 1. Most syntactic constructions are schematic patterns with at least one variable slot in which a particular set of words may be more frequently used (e.g., let alone $\mathrm{X}, \mathrm{V}$ into $\mathrm{V}$-ing, and Di-transitive). In CA, this relationship between words and constructions is referred to as "collostruction," which has been inspired by "collocation" studies (Sinclair 1991). Corpus-based collocation analyses have attested the Firthian proposition, "You shall know a word by the company it keeps" (Firth 1957:11). That is, the meaning of a word can be substantially reconstructed through an analysis of its co-occurring collocates. The collostructional analysis extends this idea to the meaning of schematic constructions by positing that one shall know the meaning of a schematic construction by examining its co-occurring words.

In CA, words that are attracted to a particular construction are referred to as collexemes. In this framework, the association is measured by rigorous statistical measures (e.g., log-transformed p-value from the Fisher-Yates Exact test), which is defined as collostrength. Similarly, pairs of collexemes that are statistically attracted to each other within a construction are referred to as co-varying collexemes (Gries \& Stefanowitsch 2004a). For instance, Stefanowitsch \& Gries (2005) investigated nominal bigrams occurring in a constructional schema of $\left[\mathrm{NP}_{1}+\right.$ of $\left.+\mathrm{NP}_{2}\right]$ in English and effectively identified a coherent set of semantic relations encoded by the covarying collexemes (e.g., $\mathrm{NP}_{1}$ and $\mathrm{NP}_{2}$ ).

Of particular relevance to the present study is the third analysis in Table $1-$ distinctive collexeme analysis (Gries \& Stefanowitsch 2004b). Given two semantically similar constructional schemas, lexemes are referred to as distinctive collexemes if they exhibit a strong preference for one member of the constructions, thus serving as distinctive words to account for the subtle semantic or functional 
differences between pairs of constructions. For example, Gries \& Stefanowitsch $(2004 \mathrm{~b})$ applied the constructionist framework to investigate the semantic difference between the dative - that is, the to-dative, (e.g., John sent a book to me) - and ditransitive alternation (e.g., John sent me a book). Their results show that these two constructions differ considerably in the verbs attracted to each. The to-dative form tends to attract verbs that denote a larger distance between the agent and the recipient, such as send or bring. On the other hand, the ditransitive form tends to attract verbs that denote a shorter distance (e.g., give and tell), which often involves face-to-face interaction.

Distinctive collexeme analysis can also be extended to consider a group of more than two near-synonymous constructions, which is referred to as a multiple distinctive collexeme analysis. For example, Gilquin (2006) adopted the CA framework to examine the differences among ten causative constructions (e.g., [X

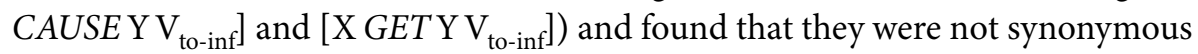
and interchangeable. Instead, they show distinctive preferences for particular sets of verbs in the non-finite $\mathrm{V}$ slot. For example, the [X CAUSE $\mathrm{Y} \mathrm{V}_{\text {to-inf }}$ ] construction attracts verbs that denote a transformation or specific movement (e.g., rise and become), while [X GET Y $\mathrm{V}_{\text {to-inf }}$ ] attracts verbs that are used to elicit words or agreement (e.g., talk, say, and agree).

Space particle constructions are schematic in the sense that each construction projects its own preferred LMs (i.e., collexemes in the CA terminology). This being the case, this study aims to explore the semantic differences among three near-synonymous space particle constructions of CONTAINMENT by examining the semantics of their co-occurring collexemes (i.e., the LM). More specifically, it is hoped that an examination of the distinctive collexemes of these three constructions may shed light on the semantic similarities and differences of these particles.

\subsection{Containment particles in Chinese}

In Chinese, the concept of CONTAINMENT is linguistically encoded by three space particles - lì, nèi, and zhōng. Of earlier studies of the semantic differences between the three spatial particles, Xing's (1996) analysis has been the most fundamental and influential. Analyzing only li and zhōng, he used intuitive data to argue that both particles can co-occur with LMs denoting a specific place, time, or event, such as xīn lǐ and xīn zhōng 'in one's heart', cūnzi lǐ and cūnzi zhōng 'in the village', and wǔ nián lǐ and wǔ nián zhōng 'in five years'. However, lǐ is more grammaticalized than zhōng and can thus sometimes be omitted; for example, nèixin lì 'in one's heart' can also be expressed as nèixìn. Furthermore, lǐ has connotations of a well-defined boundary, often contrasting with wài 'outside', as in wū lì wū wài dōu shì rén 'inside the house and outside the house are all people.' On the other hand, 
zhōng can be used with LMs denoting a process (e.g., tánpàn zhōng 'in the process of negotiation'), a certain state (e.g., fènnù zhōng 'in anger'), or a place without a boundary (e.g., kōng zhōng 'in the air'). Xing added that $l \grave{l}$ is more likely to be used with a concrete place, while zhōng is more frequently used with collective and abstract nouns.

Deng (2006) extended Xing's (1996) analysis by including the particle nèi. Most importantly, though qualitative in nature, Deng's analysis referred not only to data from native-speaker introspection, but also to attested examples from a range of corpus sources (e.g., literary works, online news forums, and corpora from Beijing University). She examined the semantic coherence of LMs which cooccurred with these three particles and highlighted four important semantic features: dimensionality, boundedness, dynamicity, and concreteness. According to her observations, li can be used with the widest range of LMs; zhōng cannot be used with LMs that serve as a boundary (e.g., mén 'door'); and nèi cannot take most abstract nouns, including nouns denoting abstract ideas, dynamic processes, and events. While both Xing's (1996) and Deng's (2006) observations are well founded, it should be noted that both analyses depend mostly on introspective data and qualitative methods, and any generalizations made need to be further tested quantitatively to ensure their reliability.

Yang (2008) also presented a qualitative analysis of these three space particles based on introspective data, making four important observations. First, Yang argues that when the inside of a large LM (e.g., dàhăi 'sea', pingyuán 'plane', and kuăngyě 'wilderness') is emphasized, Chinese speakers tend to choose zhōng instead of $l i$ to encode the COnTAInMEnT. The larger size of the LM with zhong may entail additional senses of uncertainty, or the notion that the contained TR is either floating or its location in the container is in some sense not fixed. Second, Yang argues that zhōng tends to highlight the physical centrality of the LM and carries little nuance of full containment. It tends to invite a reading of the TR moving around the LM, thus often co-occurring with LMs encoding large objects or dynamic activities. For instance, native speakers are more likely to use $z h \bar{n} g$ in huìy zhōng 'in the meeting' and jinglì zhōng 'in the experience', as the CONTAINMENT highlights only a particular stage of the event (e.g., huìi and jingli). Third, Yang adds that $l i$ often carries the meaning of full-containment: the LM is filled with the TR. In his view, speakers are more likely to say xiāngzi lì dōu shì shü 'In the box are all books' instead of xiāngzi zhōng dōu shì shü. Finally, Yang points out that nè is often preferred when the containment relation is in contrast with wài 'out', as in xiào nèi 'on campus' vs. xiào wài 'off campus'.

In contrast with previous studies, Zhang \& Liu (2008) carried out a corpusbased analysis of $l \grave{l}$, nèi, and zhōng by analyzing nouns which co-occurred with them in a one-million-character corpus. They confined their detailed examination to 
nouns referring to physical LMs and investigated the geometrical properties of the physical objects in relation to the three space particles: dimensionality (i.e., the number of dimensions the entity has), boundedness (i.e., whether the entity has a clear boundary), and porousness (i.e., whether the entity has self-contained internal space). They then analyzed the frequency distribution of different types of nouns in terms of these three semantic features. According to Zhang \& Liu, physical entities come in seven types: ${ }^{2}$ (1) three-dimensional, bounded, porous LM (e.g., píngzi 'bottle' and bàngōngshì 'office'), (2) three-dimensional, bounded, nonporous LM (e.g., dòứ 'tofu' and qiáng 'wall'), (3) three-dimensional, nonbounded, non-porous LM (e.g., shān 'mountain' and hăi 'sea'), (4) threedimensional, non-bounded, porous LM (e.g., fēng 'wind' and yŭ 'rain'), (5) twodimensional, bounded LM (e.g., jìng 'mirror' and qípán 'checkboard'), (6) twodimensional, non-bounded LM (e.g., xuědi 'snow field' and tiányě 'field'), and (7) one-dimensional (linear) LM (e.g., guìdào 'train track' and chēliú 'traffic flow'). Zhang \& Liu concluded that porousness does not seem to be involved in determining which of the three particles to choose. Boundedness can be a distinctive feature for LMs co-occurring with nèi, which prefers LMs with clear boundaries, as in guó nèi 'within the country' and xüxiàn nèi 'within the dotted line.' They also found that dimensionality plays a role in accounting for the variation in the LMs cooccurring with these three particles: while all three particles rarely co-occur with one-dimensional LMs, li co-occurs more often with three-dimensional entities and nèi with two-dimensional ones, while zhōng shows a non-biased distribution.

Zhang \& Liu's (2008) analysis marked an important step forward, providing more empirical support for the semantic variations of these near-synonymous particles of CONTAInment. Their findings in general supported claims made in previous studies (Xing 1996, Deng 2006, Yang 2008). Nevertheless, there are some limitations in Zhang \& Liu's (2008) study. First of all, Zhang \& Liu confined their examination to a particular set of LMs. While Deng (2006) examined the abstract entities in detail, Zhang \& Liu's analysis only included physical LMs. The study would be more complete if abstract LMs had also been taken into consideration when the semantic coherence of the LMs was evaluated. However, if abstract LMs had been included in the analysis, their semantic features would have had to be refined because the features (i.e., dimensionality, boundedness, porousness) used in Zhang \& Liu were based on the geometries of physical objects and not applicable to the semantic analysis of the abstract entities. Second, Zhang \& Liu based their generalizations on the frequency distribution of the co-occurrences between

2. In Zhang \& Liu's categorization, the semantic feature of boundedness is only relevant for three- and two-dimensional entities, and porousness is only relevant for three-dimensional entities. Therefore, there were seven types of LMs in their categorization. 
nouns of a given type and each particle. However, the raw frequency of a noun in a given construction can be skewed by its overall frequency in the corpus or by the overall frequency of the spatial particle construction. Therefore, if a word has a high frequency in the corpus, it could be expected to occur more frequently in the context of any given construction as well. The question is whether the noun co-occurs with the construction at a rate greater than the expected frequency. The method could be made more rigorous by incorporating proper statistical techniques and taking into consideration the potential influence of these frequencies of the space particle constructions as well as the LMs. This would give a truer indication of the salience of the observed co-occurrences.

After a comprehensive review of previous studies on CONTAINMENT particles in Chinese, we summarize them in Table 2 in terms of data, methodology, and LM semantic features.

Table 2. Comparisons of previous studies of Mandarin CONTAINMENT space particles

\begin{tabular}{|c|c|c|c|}
\hline Study & $\begin{array}{l}\text { Particles } \\
\text { analyzed }\end{array}$ & Data and method & $\begin{array}{l}\text { LM semantic } \\
\text { features }\end{array}$ \\
\hline Xing (1996) & $\begin{array}{ll}- & l \grave{\imath} \\
- & z h o ̄ n g\end{array}$ & $\begin{array}{ll}\text { - } & \text { Intuitive Data } \\
\text { - } & \text { Qualitative Approach }\end{array}$ & $\begin{array}{ll}- & \text { Boundedness } \\
- & \text { Dynamicity } \\
- & \text { Concreteness }\end{array}$ \\
\hline Deng (2006) & $\begin{array}{ll}- & l \grave{i} \\
- & n e ̀ i \\
- & z h o ̄ n g\end{array}$ & $\begin{array}{ll}\text { - } & \text { Intuitive and Attested } \\
& \text { Data } \\
\text { - } & \text { Qualitative Approach }\end{array}$ & $\begin{array}{ll}- & \text { Dimensionality } \\
- & \text { Boundedness } \\
- & \text { Dynamicity } \\
- & \text { Concreteness }\end{array}$ \\
\hline Yang (2008) & $\begin{array}{ll}- & l \grave{i} \\
- & n e ̀ i \\
- & z h o ̄ n g\end{array}$ & $\begin{array}{ll}\text { - } & \text { Intuitive Data } \\
\text { - } & \text { Qualitative Approach }\end{array}$ & $\begin{array}{ll}- & \text { Boundedness } \\
- & \text { Dynamicity } \\
- & \text { Concreteness }\end{array}$ \\
\hline $\begin{array}{l}\text { Zhang \& Liu } \\
(2008)\end{array}$ & $\begin{array}{ll}- & l \grave{i} \\
- & n e ̀ i \\
- & \text { zhōng }\end{array}$ & $\begin{array}{ll}\text { - } & \text { Corpus Data } \\
\text { - } & \text { Quantitative Approach }\end{array}$ & $\begin{array}{ll}- & \text { Dimensionality } \\
- & \text { Boundedness } \\
- & \text { Porousness }\end{array}$ \\
\hline
\end{tabular}




\section{Methodology}

\subsection{Data analysis}

The data analyzed in this study came from the Academia Sinica Balanced Corpus of Modern Chinese 4.0 (hereafter, Sinica Corpus) (Huang \& Chen 2010), which consists of around ten million words of texts collected between 1981 and 2007, covering different topics and genres. Every text in the corpus has been segmented into words and annotated with part-of-speech (POS) tags.

Figure 1 provides a flow chart of the data analysis. We first used regular expressions to extract the target space particle construction (hereafter, SPC), [zài NP lí/nèi/zhōng] with self-developed scripts written in R. Each token was manually checked and corrected in case of false-positive results. After manual screening, 15,290 instances of SPCs were included for analysis: 12,388 tokens of [zài NP zhōng], 1,583 tokens of [zài NP lì], and 1,319 tokens of [zài NP nèi].

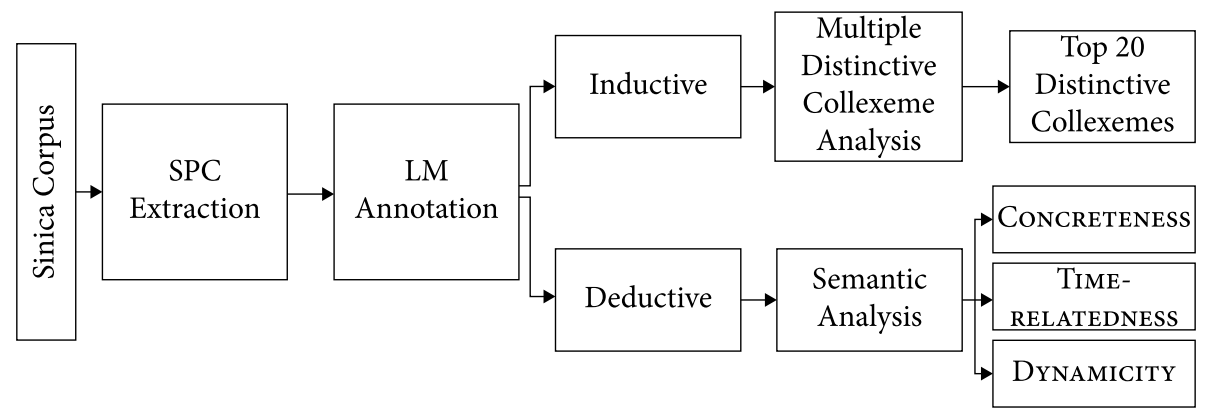

Figure 1. Data analysis flow chart

For each token, the head noun (i.e., LM) was identified as follows. First, we used regular expressions to retrieve the rightmost lexical item tagged as a noun appearing before the space particle in the construction. This was based on the leftbranching characteristic of the NP structure in Chinese, where the head noun was often positioned at the end of the whole NP. All extracted head nouns were then manually checked and corrected to ensure the accuracy of the LM head noun.

After identifying the head noun of each SPC (i.e., LM Annotation in Figure 1), we performed our corpus-based analyses from two perspectives (i.e., inductive and deductive approaches), as indicated in Figure 1. First, we applied the multiple distinctive collexeme analysis (hereafter, MDCA) to determine the significant distinctive LMs that were more strongly associated with one particular space particle. This method allowed us to uncover the possible underlying semantic features of each space particle by exploring the semantic coherence of their top 20 distinctive 
collexemes ranked according to their distinctiveness values. The first analysis served as an inductive and exploratory method to examine the shared semantic properties of LMs co-occurring with these three SPCs with little a priori generalization of their semantic commonalities. Additionally, we tested the semantic features discussed in the previous literature (cf. Section 2.2) quantitatively by performing systematic semantic analyses on three important semantic features: CONCRETENess, time-Relatedness, and dynamicity (i.e., Semantic Analysis in Figure 1). The second analysis served as a deductive approach to seek empirical support for the appropriateness and importance of the generalizations made by previous studies (cf. Table 2).

\subsection{Multiple distinctive collexeme analysis}

This section illustrates how to calculate the association strength between the LM and the space particle in the SPC using the MDCA. The data analysis was performed with R scripts utilizing the package of Coll.Analysis 3.2 written by Stefan Gries $^{3}$ (Gries 2009).

Let us illustrate the procedure with a particular LM, nián 'year'. To determine whether nián was distinctive in differentiating the meanings of the three space particles, we first tallied its co-occurrence frequencies with each construction, as shown in the Observed Frequency column in Table 3. Based on the marginal frequencies of the constructions, we computed the expected frequencies of nián for each construction. For each construction, a binomial test was then performed to establish the exact probability of observing these co-occurrence frequencies given the expected frequencies. The log-transformed probability (in base 10) was defined as the distinctiveness value of the collexeme nián. According to Gries \& Stefanowitsch (2004b), the distinctiveness value determines whether a collexeme is significantly distinctive for a particular construction. Normally, a distinctiveness value greater than 2 (or less than -2 ) would suggest that the $p$ value is smaller than the normal significance level (i.e., o.o1), thus indicating a frequency distribution significantly different from that expected (Gilquin 2006). The sign of the distinctiveness value suggests either attraction or repulsion. As shown in Table 3, nián was more attracted to the nèi construction and was strongly repelled by the zhōng construction.

Additionally, the analysis also provided the sum of all absolute distinctiveness values (SumAbsDev) for each collexeme, measuring how strongly each collexeme

3. The package is available on Stefan Gries's website. Please refer to his book (Gries 2009) as well as his website for more instructions on Coll.analysis.r: http://www.linguistics.ucsb.edu /faculty/stgries/teaching/groningen/index.html 
Table 3. Multiple distinctive collexeme analysis (MDCA)

\begin{tabular}{|c|c|c|c|c|c|c|c|c|c|c|c|}
\hline \multirow[b]{2}{*}{ Collexeme } & \multicolumn{3}{|c|}{$\begin{array}{l}\text { Observed } \\
\text { frequency }\end{array}$} & \multicolumn{3}{|c|}{$\begin{array}{l}\text { Expected } \\
\text { frequency }\end{array}$} & \multicolumn{3}{|c|}{$\begin{array}{c}\text { Distinctiveness } \\
\text { value }\end{array}$} & \multirow[b]{2}{*}{ SumAbsDev } & \multirow[b]{2}{*}{ LargestDev } \\
\hline & $\frac{\sqrt{n}}{3}$ & : & $\approx$ & $\frac{\substack{n \\
\frac{1}{N}}}{20}$ & 脑 & $\approx$ & 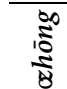 & 异 & $\therefore$ & & \\
\hline nián 'year' & $\tilde{6}$ & $\begin{array}{l}0 \\
\stackrel{n}{N}\end{array}$ & m & 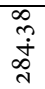 & 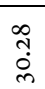 & $\stackrel{+}{\stackrel{m}{\infty}}$ & $\underset{⿱ ㇒}{\stackrel{7}{7}}$ & 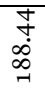 & $\begin{array}{l}\hat{\imath} \\
\hat{i}\end{array}$ & 332.14 & nèi \\
\hline
\end{tabular}

deviated from the expected distribution, and the largest deviation (LargestDev), identifying the construction from which the collexeme showed the strongest deviation. Please note that these values measured a non-directional deviation, which could be a relationship of either attraction or repulsion. Table 3 included all the statistics provided by the MDCA for the LM nián. In the case of nián, SumAbsDev was 332.142 and the strongest deviation was for the nèi construction, with the positive value suggesting an attraction. The same procedure was applied to all LM types in our data.

\subsection{Semantic analysis}

There were three reasons for conducting the second deductive post-hoc semantic analysis. First, the MDCA provided an indication of the semantic preference of each SPC based on the ranking of the top $N$ distinctive collexemes. However, we needed a more holistic analysis, including as many collexemes as possible in order to provide a more comprehensive account of the semantic cohesion of these distinctive collexemes. Second, the MDCA had its own limitation of giving high distinctive values to low-frequency collexemes. For example, dēngying 'light shadow', which is the 2oth most distinctive collexeme in the li construction, only appeared four times in our data. Such data might be less effective in giving us a generalizable pattern of the semantic cohesion for each construction. Finally, the MDCA started out as an inductive analysis for constructional semantic coherence by identifying distinctive collexemes in a piecemeal fashion. This inductive approach could be complemented by a more deductive approach. As summarized in Section 2.2, previous studies of these SPCs have identified several important semantic features of LMs that are relevant to the distinction of these three particles. Our second analysis served as a corpus-based deductive approach to quantitatively determine the effectiveness of these semantic features in accounting for the variation among the SPCs.

Our second analysis started with a down-sampling procedure, which enabled us to filter out low-frequency tokens but maintain the representativeness of the 
data. More specifically, we included nouns ${ }^{4}$ with a frequency of over 5 and which were attracted to a particular SPC (i.e., distinctiveness value $>2$ ). Applying this threshold yielded a down-sampled data set of 406 types of noun in total, with 6014 occurrences of the zhōng construction, 1141 of nèi, and 775 of li. A comparison of the original and the down-sampled data sets is provided in Table 4.

Table 4. Data sizes for post-hoc semantic analysis

\begin{tabular}{llcc}
\hline & & Original dataset & Down-sampled dataset \\
\hline Token frequency & {$[$ zà̀ NP lì $]$} & 1583 & $775(49 \%)$ \\
& {$[$ zài NP nèi $]$} & 1319 & $1141(87 \%)$ \\
Type frequency & {$[$ zài NP zhōng $]$} & 12388 & $6014(49 \%)$ \\
& {$[$ zài NP lì $]$} & 685 & $165(24 \%)$ \\
Total token frequency & {$[$ zài NP $z h o ̀ i n g]$} & 184 & $56(30 \%)$ \\
Total type frequency & & 3872 & $401(10 \%)$ \\
\hline
\end{tabular}

The next step was to select a set of relevant semantic features relating to the LM based on the findings of previous research and further test their effectiveness in accounting for the semantic differences between these three particles. One important methodological consideration in our second semantic analysis was that each semantic feature considered had to be applicable to all LMs, including both concrete and abstract entities. To begin with, as previous studies have suggested that the CONCRETENESS and DYNAMICITY of the LMs are crucial to the semantic distinction of these three particles (Xing 1996, Deng 2006, Yang 2008), these two semantic fields of the LMs were evaluated in a more quantitative way in our second analysis.

CONCRETENESS examined whether the concreteness of the LM played a role in differentiating these SPCs. It categorized all LM types into four sub-groups: three-dimensional concrete nouns (e.g., diànnǎo 'computer'), two-dimensional concrete nouns (e.g., wénzhāng 'article' and xuědi 'snow field'), organization (e.g., dăng 'political party'), and abstract nouns (e.g., xīwàng 'hope'). Organization nouns referred to collective human groups with individuals sharing the same goal (Zaenen et al. 2004), and were thus distinct from the other abstract nouns in our

4. Throughout this study, we will use "noun" to refer to the "head noun" of the NP in the [zài NP lǐ/nèi/zhōng] construction. While the term "noun" may be seen as a short-hand for the NP, we acknowledge that the identification of the head noun for an NP may be subject to the word segmentation provided by the Sinica Corpus. 
categorization. They were included as a particular class because previous work has suggested that they are relevant to meaning distinctions among uses of the CONTAINMENT particles (Deng 2006).

DYNAMICITY examined the degrees to which the LM referred to a dynamic event. Previous studies have suggested that LMs denoting dynamic activities tend to select zhōng as the preferred particle (Xing 1996, Deng 2006, Yang 2008). In our analysis, DYNAMICITY was based on two operational criteria: [ \pm PROCESs] and $[ \pm$ VERBAL $]$. [ \pm PROCESS] referred to whether the LM represented an activity that had a time course. [ \pm VERBAL] referred to a morphosyntactic property of a noun. In Chinese, there are nouns ${ }^{5}$ (e.g., jingli '(to) experience') that are so high in dynamicity that they can serve as the main predicate of a sentence without additional derivation or structural coding. Following these two criteria, we categorized all the LMs into three sub-groups according to their dynamicity, as summarized in Table 5. These three types formed a continuum of dynamicity with non-process nouns being the least dynamic and verbal process nouns the most.

Table 5. Dynamicity

\begin{tabular}{lccl}
\hline & [+PROCESS] & [+VERBAL] & Example \\
\hline Non-process nouns & - & - & guānxi 'relationship' \\
Non-verbal process & + & - & huìỳ 'meeting' \\
nouns & & & \\
Verbal process nouns & + & + & tăolùn 'discussion' \\
\hline
\end{tabular}

In Table 2, a comparison of previous studies, there remained a couple of unattended semantic features suggested by the previous analyses. First of all, porousness was not considered in this study because it has been shown to have rather limited explanatory power in differentiating among the three particles (Zhang \& Liu 2008). Second, the semantic feature of dimensionality was combined with CONCRETENESS in our analysis by dividing concrete entities into more finegrained sub-categories (i.e., three-dimensional or two-dimensional entities). As for the semantic feature of boundedness, our study considered this semantic feature in an indirect way. Additionally, the CONCRETENEss considered the boundedness of entities by identifying the physical boundaries of the concrete entities (i.e., three-dimensional or two-dimensional entities). On the other hand, our

5. Use of the label "noun" does not strictly speaking apply here. Parts-of-speech in Chinese are usually not morphologically transparent, and the syntactic categories of the words are often highly dependent on context. We use the label "noun" only as a short-hand to refer to those words occurring in the NP position of the [zai NP lǐ/nèi/zhōng]. 
DYNAMICITY considered the boundedness by highlighting the telicity of the processes or activities (i.e., non-verbal process nouns and verbal process nouns). Finally, as Boroditsky (200o) pointed out that spatial particles are often closely related to how we conceptualize time, temporal entities were particularly isolated in our analysis as an independent semantic feature to see if the timerelatedness of the LMs plays a role in differentiating among these three space particles. Deng (2006) also investigated the interactions between temporal expressions and three constructions; however, she did not discuss the tendency in a quantitative way, i.e., which construction was more likely to go with the temporal expressions. Consequently, the last semantic feature included in our second analysis was TIME-RELATEDNESS, which concerned the temporal relevance of the LMs. All LMs were categorized into three sub-groups: time units, time durations, and atemporal entities. Time units were defined as the time expressions that could directly take a numeral. For example, rì 'day' was a time unit because it can be quantified by numerals, e.g., wǔ rì 'five days.' Time durations referred to time expressions that were not time units. For example, duănqí 'short term' was a time duration noun. All other nouns that did not fall into the previous two categories were categorized as atemporal nouns. ${ }^{7}$

6. We acknowledge the fact that while nián is a time unit, the whole noun phrase wǔ nián 'five year' may refer to a time duration. In our analysis, we used the word segmentation provided by the Sinica Corpus. In a phrase like zài táidà de wǔ nián lǔ 'in the five years at National Taiwan University', wǔ and nián are segmented as two words in the Sinica Corpus. Therefore, we identified nián as the head noun of the SPC, instead of wǔ nián. This study took the head noun as the basis of the distinctive collexeme analysis. This not only ensured consistency and replicability in our identification of the head noun, but also uncovered different patterns for time units and time durations.

7. One reviewer suggested the very interesting possibility of having another sub-category of "space unit nouns" (e.g., rén 'people'), where a concrete entity serves as a base unit. An example from our corpus is as follows: zài bèi diàochá de wǔqiān dū rén zhōng 'among these five thousand or so people under investigation'. As these nouns tend to refer to concrete entities in the real world, our current annotations would mark them as " 3 D Concrete" in terms of CONCRETENESS, "atemporal" in terms of TIME-RELATEDNESs, and "non-process" in terms of DYNAMicity. The present study did not isolate this class of nouns as a sub-category of TIME-RELATEDNESS or an independent semantic feature for analysis for two reasons. First, our preliminary observation suggested that concrete nouns that could serve as counting units may not be as frequent as temporal nouns in our data and a coherent semantic feature related to this "space unit" may not be easily identified. On the other hand, it is less clear how to operationalize the notion of a "space unit." While the co-occurrence of these concrete nouns with numerals may provide strong clues, sometimes the obligatoriness of the classifiers may introduce confusion. For example, while we can say zài zhè bā rén zhōng 'among these eight people', it seems odd to say zài zhè $b \bar{a}$ shü zhōng 'among these eight books.' The semantic feature underlying these "space units" 
After the manual annotation of the semantic types for all LMs in the downsampled dataset, the results were cross-tabulated in three contingency tables (cf. Tables 10-14 in Section 4.2) and submitted to chi-square tests to determine the significance of the association of each semantic feature (i.e., CONCRETENESS, TIME-RELATEDNESS and DyNAmicity) and the SPC alternation. The purpose of the second analysis was to tease apart the crucial semantic features that were distinctive in accounting for the meaning differences of these space particles.

It should be noted that each semantic feature in our study examined a particular aspect (or semantic field) of the LM semantics independently. The subcategories of each semantic feature did not have a direct one-to-one mapping. For example, while the time-related nouns (i.e., time unit and time duration) were all abstract nouns, not all abstract nouns were necessarily time-related. Atemporal nouns could refer to either concrete or abstract entities. Similarly, while all the process nouns (i.e., non-verbal and verbal) were abstract nouns, not all abstract nouns were process nouns. Non-process nouns could refer to either concrete or abstract entities. This feature-based semantic analysis of the LMs allowed us to determine the importance of each semantic field in relation to the SPC alternation independently. Table 6 provides a mapping of the sub-categories of our three semantic features.

Table 6. Sub-category mapping of the three semantic features

\begin{tabular}{llll}
\hline Semantic features & Concreteness & Time-relatedness & Dynamicity \\
\hline Sub-categories & 3D Concrete & Atemporal & Non-process \\
& 2D Concrete & & \\
& Organization & & \\
& Abstract & Time Unit & \\
& & Time Duration & \\
& & Atemporal & Non-verbal Process \\
& & & Verbal Process \\
\hline
\end{tabular}

may not be as intuitive as TIME-RELATEDNESs for temporal nouns. As concrete LMs observed in the Sinica Corpus are in general low in frequency, we are open to the possibilities of the importance and appropriateness of the space unit nouns, which may open avenues for future research when we examine the use of SPCs in more diverse genres/registers. 


\section{Results}

\subsection{Multiple distinctive collexeme analysis}

\subsection{1 [zài NP nèi]}

Table 7 shows the top 20 distinctive collexemes for [zài NP nèi], which were ranked according to their distinctiveness values. The collexeme nian 'year', as illustrated in (2), is the most distinctive collexeme for nèi. It is a temporal noun (i.e., time unit). Other temporal nouns that can function as time units are also included on the list, such as yuè 'month', xiăoshí 'hour', tiān 'day', fēnzhōng 'minute', zhōu 'week', rì 'day', xingqi 'week', and miăo 'second. The other temporal nouns include duănqi 'short term', duănshijiān 'short time', jìnqi 'recent days', qíxiàn 'time limit', and jinrì 'recent days'. In other words, among the top 20, seventeen collexemes $(85 \%)$ are time-related nouns, suggesting a strong preference for [zài NP nèi] to take temporal entities.

(2) Tā jìhuà zài yī nián nèi wánchéng shòu shēn, xīwàng jiăn diào 50 zhì 70 he plan ZAI one year NEI finish thin body wish lose to 50 to 70 gōngjīn.

kilogram

'He planned to lose weight in one year and hoped to lose 50 to 70 kilograms.'

\subsection{2 [zài NP zhōng]}

Based on the ranking of the distinctiveness values, Table 8 shows the top 20 distinctive collexemes for [zài NP zhōng]. The first-ranked distinctive collexeme is guòchéng 'process', as illustrated in (3).

(3) Shēn xīn zhàngài zhě zài yīliáo huò chóngfăn shèhuì shìying physical mental disabled people ZAI medical or return society adjust guòchéng zhōng wăngwăng yào chéngshòu xǔduō de cuòzhé yǔ process ZHONG often need bear many DE frustration and jǔsàng qíngxù.

depression emotion

'Mentally or physically challenged people often need to bear much frustration and depression in the process of medical treatment or social adjustment.'

The zhōng construction in the sentence refers to being at a certain stage of social adaptation for those who are physically or mentally disabled. The LM guòchéng refers to a process consisting of several stages, as well as different actions (Menzel 1975), and it is regarded as a non-verbal process noun with distinctive internal stages. Another process noun on the top 20 list is huiyi 'meeting. In a meeting, we follow certain conventions, for example, introducing the members, presenting an 
Table 7. Top 20 distinctive collexemes for [zài NP nèi]

\begin{tabular}{|c|c|c|c|c|c|c|}
\hline LM & $\mathrm{N}$ & Gloss & Concreteness & $\begin{array}{l}\text { Time- } \\
\text { relatedness }\end{array}$ & Dynamicity & Distinctiveness \\
\hline nián & 256 & year & Abstract & Unit & Non-process & 188.44 \\
\hline shijiān & 150 & time & Abstract & Duration & Non-process & 114.47 \\
\hline yuè & 114 & month & Abstract & Unit & Non-process & 104.54 \\
\hline duănqī & 71 & short term & Abstract & Duration & Non-process & 73.73 \\
\hline xiăoshí & 70 & hour & Abstract & Unit & Non-process & 67.44 \\
\hline tiān & 79 & day & Abstract & Unit & Non-process & 64.20 \\
\hline fànwéi & 61 & range & Abstract & Atemporal & Non-process & 55.29 \\
\hline fēnzhōng & 39 & minute & Abstract & Unit & Non-process & 38.66 \\
\hline qíjiān & 30 & period & Abstract & Duration & Non-process & 29.30 \\
\hline$z h \bar{u} u$ & 28 & week & Abstract & Unit & Non-process & 27.23 \\
\hline jìnq̄i & 25 & $\begin{array}{l}\text { recent } \\
\text { days }\end{array}$ & Abstract & Duration & Non-process & 25.22 \\
\hline duănshíjiān & 23 & short time & Abstract & Duration & Non-process & 24.47 \\
\hline rì & 24 & day & Abstract & Unit & Non-process & 23.10 \\
\hline$z h o \bar{u}$ & 17 & week & Abstract & Unit & Non-process & 18.09 \\
\hline qīxiàn & 19 & time limit & Abstract & Duration & Non-process & 17.97 \\
\hline xìngqì & 16 & week & Abstract & Unit & Non-process & 14.15 \\
\hline miǎo & 15 & second & Abstract & Unit & Non-process & 13.90 \\
\hline jìnrì & 13 & $\begin{array}{l}\text { recent } \\
\text { days }\end{array}$ & Abstract & Duration & Non-process & 12.72 \\
\hline dăng & 8 & party & Organization & Atemporal & Non-process & $7 \cdot 59$ \\
\hline guómíndǎng & 6 & $\begin{array}{l}\text { Nationalist } \\
\text { Party }\end{array}$ & Organization & Atemporal & Non-process & 6.38 \\
\hline
\end{tabular}

issue, discussion, and voting. It refers to a bounded event with clear time duration. Out of the top 20 distinctive collexemes, fifteen collexemes (75\%) were process nouns. Considering that the majority of the top 20 distinctive collexemes fall into the category of process nouns, we may conclude that the semantic property of dynamicity is closely related to [zài NP zhōng].

\subsection{3 [zài NP lì]}

Most previous analyses claim that $l i$ can co-occur with a greater diversity of nouns compared to the other two particles (Deng 2006, Yang 2008). Our MDCA suggests that $l_{i}$ does attract a much wider range of nouns with more diverse semantic properties than those observed in the zhōng and nèi constructions. As can be seen in Table 9, ten out of the top $20(50 \%)$ distinctive collexemes are abstract nonprocess nouns: shèhuì 'society', jìyì 'memory', guódì 'country', guānniàn 'concept', 
Table 8. Top 20 distinctive collexemes for [zài NP zhōng]

\begin{tabular}{|c|c|c|c|c|c|c|}
\hline LM & $\mathrm{N}$ & Gloss & Concreteness & $\begin{array}{l}\text { Time- } \\
\text { relatedness }\end{array}$ & Dynamicity & Distinctiveness \\
\hline guòchéng & 847 & process & Abstract & Atemporal & $\begin{array}{l}\text { Non-verbal } \\
\text { Process }\end{array}$ & 49.75 \\
\hline shēnghuó & 270 & life & Abstract & Atemporal & Verbal Process & 14.71 \\
\hline huódóng & 102 & activity & Abstract & Atemporal & Verbal Process & 9.32 \\
\hline $\operatorname{sh} \bar{u}$ & 186 & book & ${ }_{3} \mathrm{D}$ Concrete & Atemporal & Non-process & 7.84 \\
\hline huìyi & 94 & meeting & Abstract & Atemporal & Verbal Process & 7.31 \\
\hline gōngzuò & 64 & work & Abstract & Atemporal & Verbal Process & 5.85 \\
\hline piàn & 61 & video clip & Abstract & Atemporal & Non-process & 5.57 \\
\hline bàogào & 70 & report & Abstract & Atemporal & Verbal Process & 5.24 \\
\hline huì & 53 & meeting & Abstract & Atemporal & $\begin{array}{l}\text { Non-verbal } \\
\text { Process }\end{array}$ & 4.84 \\
\hline bùzhībùjué & 40 & unconsciousness & Abstract & Atemporal & Non-process & 3.65 \\
\hline xíngdòng & 40 & action & Abstract & Atemporal & Verbal process & 3.65 \\
\hline jìzhěhuì & 40 & press conference & Abstract & Atemporal & $\begin{array}{l}\text { Non-verbal } \\
\text { Process }\end{array}$ & 3.65 \\
\hline wén & 60 & article & 2D Concrete & Atemporal & Non-process & 3.59 \\
\hline bisài & 60 & match & Abstract & Atemporal & Verbal Process & 3.59 \\
\hline xuănjǔ & 50 & election & Abstract & Atemporal & Verbal Process & 3.54 \\
\hline shijiàn & 48 & event & Abstract & Atemporal & $\begin{array}{l}\text { Non-verbal } \\
\text { Process }\end{array}$ & 3.38 \\
\hline yóuxì & 34 & game & Abstract & Atemporal & $\begin{array}{l}\text { Non-verbal } \\
\text { Process }\end{array}$ & 3.10 \\
\hline diàochá & 32 & investigation & Abstract & Atemporal & Verbal Process & 2.92 \\
\hline shèng & 31 & voice & Abstract & Atemporal & Non-process & 2.83 \\
\hline jiémù & 50 & $\mathrm{TV}$ program & Abstract & Atemporal & $\begin{array}{l}\text { Non-verbal } \\
\text { Process }\end{array}$ & 2.81 \\
\hline
\end{tabular}

năohăi 'mind', mèng 'dream', àiqíng 'love', shēngmìng 'life', guānxī 'relationship', and $x \bar{u} k \bar{n} n$ ' 'emptiness'. (These nouns neither refer to a dynamic process/activity nor do they have the morphological potential of being used as the main predicate of a sentence.) These abstract non-process nouns denote an undifferentiated period, a state-like property with little internal temporal duration, as in (4). In addition, there are four time-related nouns (rìi 'day', shídài 'era', niándài 'age', dōngjì 'winter'), five concrete nouns (yăn 'eye', xīn 'heart', rìji 'diary', dēngy̌̀ng 'shadow cast by a light', tiāndì 'world'), and one non-verbal process noun ( $x \grave{i}$ 'play, stage performance'). While lì may co-occur with more diverse LMs than zhōng and nèi, it should be noted that it is the only particle of the three SPCs whose top collexemes include more instances of concrete entities. Also, this ranked list suggests that $l i$ 
rarely takes high-dynamicity nouns, because only one non-verbal process noun is on the list and no verbal process noun appears. Therefore, our results suggest that the semantic features of the LMs in the li construction are more heterogeneous than those of the other two particles and tend to repel dynamic process nouns. Compared to the other two particles, the top 20 collexeme list of the li construction implies a less conclusive pattern for the shared semantic properties of its cooccurring LMs.

(4) Zài fùzá de rénjì guānxī lǐ, bù zūnzhòng zìjǐ zé ZAI complicated DE interpersonal relationship LI NEG respect oneself then dé bú dào biérén de zūnzhòng.

receive NEG to others DE respect

'In complex interpersonal relationships, if you don't respect yourself, you will not get respect from others as well.'

Table 9. Top zo distinctive collexemes for [zài NP lỉ

\begin{tabular}{|c|c|c|c|c|c|c|}
\hline LM & $\mathbf{N}$ & Gloss & Concreteness & $\begin{array}{l}\text { Time- } \\
\text { relatedness }\end{array}$ & Dynamicity & Distinctiveness \\
\hline rizi & 51 & day & Abstract & Unit & Non-process & 44.88 \\
\hline$x \bar{i} n$ & 126 & heart & $3 \mathrm{D}$ Concrete & Atemporal & Non-process & 33.33 \\
\hline shídài & 24 & era & Abstract & Duration & Non-process & 12.59 \\
\hline shèhuì & 49 & society & Abstract & Atemporal & Non-process & 7.20 \\
\hline Jiyì & 21 & memory & Abstract & Atemporal & Non-process & 7.12 \\
\hline niándài & 12 & age & Abstract & Duration & Non-process & 7.06 \\
\hline guódù & 8 & country & Organization & Atemporal & Non-process & 6.96 \\
\hline$x i$ & 16 & play & Abstract & Atemporal & $\begin{array}{l}\text { Non-verbal } \\
\text { Process }\end{array}$ & 6.78 \\
\hline guānniàn & 15 & concept & Abstract & Atemporal & Non-process & 6.34 \\
\hline tiāndì & 7 & world & $3 \mathrm{D}$ Concrete & Atemporal & Non-process & 6.03 \\
\hline năohăi & 11 & brain & Abstract & Atemporal & Non-process & 5.71 \\
\hline văn & 51 & eye & 3 D Concrete & Atemporal & Non-process & 5.14 \\
\hline mèng & 13 & dream & Abstract & Atemporal & Non-process & 4.44 \\
\hline àiqíng & 7 & love & Abstract & Atemporal & Non-process & 4.20 \\
\hline shēngmìng & 14 & life & Abstract & Atemporal & Non-process & 4.04 \\
\hline dēngying & 4 & $\begin{array}{l}\text { light } \\
\text { shadow }\end{array}$ & 2D Concrete & Atemporal & Non-process & 3.93 \\
\hline rìjì & 9 & diary & 2D Concrete & Atemporal & Non-process & 3.71 \\
\hline guānxi & 14 & relationship & Abstract & Atemporal & Non-process & 3.38 \\
\hline dōngjì & 4 & winter & Abstract & Duration & Non-process & 3.27 \\
\hline$x \bar{u} k \bar{o} n g$ & 4 & emptiness & Abstract & Atemporal & Non-process & 3.27 \\
\hline
\end{tabular}




\subsection{Semantic analyses}

This section presents the statistical results of the Chi-square analyses. In each table (Tables 10-12), we provide (1) the raw and expected frequencies of the data, (2) the test statistics $\left(\chi^{2}\right)$ and significance tests, (3) effect sizes (Cramer's $V$ ), and (4) chi-square standardized residuals. The standardized residuals in each cell of the table allowed us to examine the differences between the observed and the expected frequencies in each cell in the contingency tables. A positive residual value higher than +1.96 suggested a strong positive relationship between the semantic sub-group and the space particle (i.e., attraction); a negative residual value lower than -1.96 suggested a strong negative relationship between the semantic sub-group and the space particle (i.e., repulsion). Significant patterns have been highlighted in black (i.e., attraction) and gray (i.e., repulsion).

\subsubsection{CONCRETENESS}

As shown in Table 10, the chi-square test shows that the correlation between different types of CONCRETENESS and the SPC alternation is very significant $\left(\chi^{2}=283.31 ; d f=6 ; p<.001\right.$; Cramer's $\left.V=0.13\right)$.

Table 10. Chi-square test residuals for CONCRETEness

\begin{tabular}{|c|c|c|c|c|c|}
\hline \multicolumn{2}{|c|}{$\begin{array}{l}\chi^{2}=283.31 ; d f=6 ; p<.001 \\
\text { Cramer's } V=0.13\end{array}$} & \multirow{2}{*}{$\begin{array}{l}\text { 3D-concrete } \\
\text { Nouns } \\
156\end{array}$} & \multirow{2}{*}{$\begin{array}{c}\begin{array}{c}\text { 2D-concrete } \\
\text { Nouns }\end{array} \\
45\end{array}$} & \multirow{2}{*}{$\begin{array}{c}\begin{array}{c}\text { Organization } \\
\text { Nouns }\end{array} \\
16\end{array}$} & \multirow{2}{*}{$\begin{array}{c}\begin{array}{c}\text { Abstract } \\
\text { Nouns }\end{array} \\
558\end{array}$} \\
\hline$[z a ̀ i$ NP lì $]$ & Observed N & & & & \\
\hline & Expected N & 78.77 & 35.76 & 17.59 & 642.86 \\
\hline & Residual & 8.70 & 1.54 & -0.37 & $-3 \cdot 34$ \\
\hline \multirow[t]{3}{*}{ [zài NP nèi] } & Observed $\mathrm{N}$ & o & 7 & 22 & 1112 \\
\hline & Expected N & 115.97 & 52.66 & 25.89 & 946.46 \\
\hline & Residual & -10.76 & -6.29 & -0.76 & 5.38 \\
\hline \multirow[t]{3}{*}{ [zài NP zhōng] } & Observed N & 650 & 314 & 142 & 4908 \\
\hline & Expected N & 611.25 & 277.56 & 136.50 & 4988.66 \\
\hline & Residual & 1.56 & 2.186 & 0.46 & -1.14 \\
\hline
\end{tabular}

In [zài NP lị], our analysis shows that this construction tends to repel abstract nouns and attract more concrete nouns. ${ }^{8}$ This patterning is consistent with Xing's

8. One of the reviewers points out that this statement seems paradoxical when compared to our earlier observation regarding the MDCA that 10 of the top 20 collexemes for $l i$ are "abstract nouns." We would like to stress that the top 20 collexeme list provides only a rough approximation of the semantic coherence of the LMs co-occurring with each SPC. Unless the semantic coherence of these top 20 collexemes is statistically straightforward (e.g., over $80 \%$ of the nouns 
(1996) observation that $l i$ is more likely to co-occur with concrete nouns. In addition, in our results $l i$ tends to co-occur with three-dimensional concrete nouns. This patterning aligns with Zhang \& Liu (2008) and further supports our earlier observation regarding the MDCA that only concrete LMs appear in the top 20 collexeme list of the lì construction.

As for [zài NP nèi], our results show that it tends to co-occur with abstract nouns. As shown by the top collexemes in our earlier MDCA, most abstract nouns co-occurring with nèi are time-related, such as xìngqi 'week', tiān 'day', and yuè 'month'. While Zhang \& Liu (2008) claim that nèi is more likely to co-occur with two-dimensional nouns, the present study did not find quantitative support for this. Instead, our data suggest that in general this construction repels concrete nouns as LMs.

As for [zài NP zhōng], it shows a positive correlation with two-dimensional concrete nouns (e.g., zài shī zhōng 'in books'); however, based on the scales of the standardized residuals, the correlation is not as strong as that of the others. In Zhang \& Liu (2008), zhōng is equally distributed among two and threedimensional nouns, which is consistent with our similar standardized residuals of three-dimensional and two-dimensional nouns with zhōng. In addition, zhōng does not show a strong preference for the other noun types, suggesting that some other semantic features may be involved in further distinguishing the nouns that co-occur with zhōng.

In summary, the general preferences of the three constructions in relation to CONCRETENESS are: (1) lì tends to co-occur with concrete nouns; (2) nèi tends to co-occur with abstract nouns; and (3) zhōng generally did not show a strong preference in terms of the concreteness of the LMs. The effect size for the correlation between CONCRETENESS and constructional choice is moderate (Cramer's $V=0.13)$, which suggests that other semantic features of the co-occurring nouns may be missing.

belonging to a semantic group, as observed for the zhōng and nèi constructions), this ranked list may tell us little about the shared semantic properties of the LMs for the li construction. The heterogenous semantic distribution of the top 20 collexemes of $l i$ may indicate that the semantics of its LMs is more complex. Statistically, the semantic distribution of the top 20 collexemes for li (i.e., 10 Non-process, 4 Time-related, 5 Concrete, and 1 Process nouns) does not reach statistical significance either $\left(\chi^{2}=8.4 ; d f=3 ; p>.01\right)$. Therefore, while $50 \%(10 / 20)$ of the top 20 collexemes are abstract nouns and their summed frequencies are 88 , this does not suggest that the $l i$ construction "attracts" abstract nouns. Rather, our MDCA suggests that a further semantic analysis is needed to pin down the shared semantic properties of the LMs in the li construction. 


\subsubsection{TIME-RELATEDNESS}

The chi-square test suggests that the correlation between TIME-RELATEDNESS and the SPC alternation is highly significant with a large effect size $\left(\chi^{2}=4452.1 ; d f<4\right.$; $p<.001$; Cramer's $V=0.53$ ). The residual analysis is provided in Table 11.

Table 11. Chi-square test residuals for TIME-RELATEDNESS

\begin{tabular}{llccc}
\hline$\chi^{\mathbf{2}}=\mathbf{4 4 5 2 . 1} ; d f=\mathbf{4} ; \boldsymbol{p}<\mathbf{. 0 0 1}$ Cramer's $V=\mathbf{0 . 5 3}$ & Time unit & Time duration & Atemporal nouns \\
\hline$[$ zài NP li] & Observed N & 45 & 174 & 556 \\
& Expected N & 71.73 & 64.20 & 639.05 \\
& Residual & -3.15 & 13.70 & -3.28 \\
{$[$ zài NP nèi $]$} & Observed N & 591 & 345 & 205 \\
& Expected N & 105.61 & 94.53 & 940.85 \\
& Residual & 47.23 & 25.76 & -23.99 \\
{$[$ zài NP zhōng] } & Observed N & 98 & 138 & 5778 \\
& Expected N & 556.65 & 498.25 & 4959.08 \\
& Residual & -19.43 & -16.13 & 11.62 \\
\hline
\end{tabular}

The large effect size suggests that TIME-RELATEDNESS is an effective and distinctive semantic feature which distinguishes the three constructions. Deng (2006) observed that all three constructions can take temporal expressions. Our data suggest that $l i$ and nèi are more connected to LMs denoting temporal concepts, while zhōng has a much weaker correlation with temporal expressions. As for lĭ and nèi, $l \grave{l}$ shows only a preference for time duration nouns, but nèi shows an equal preference for both types of time-related noun (i.e., time units and durations).

In summary, the general preferences of the three constructions in relation to TIME-RELATEDNESS are: (1) li tends to co-occur with time duration nouns; (2) nèi tends to co-occur with time unit and time duration nouns; and (3) zhōng tends to co-occur with atemporal nouns.

\subsubsection{DYNAMICITY}

The correlation between DYNAMICITY and the SPC alternation is very significant $\left(\chi^{2}=1024.1 ; d f=6 ; p<.001 ;\right.$ Cramer's $\left.V=0.25\right)$. The residual analysis is shown in Table 12.

The substantial effect size suggests that DYNAMICITY accounts for a considerable part of the variation in the SPC alternation. The [zài NP lì] construction shows a positive correlation with non-process nouns and repels process nouns in general. While Deng (2006) observed that both lì and zhōng could take dynamic expressions (i.e., process nouns), our results do not identify this as a significant 
Table 12. Chi-square test residuals for DYNAMICITY

\begin{tabular}{|c|c|c|c|c|}
\hline \multicolumn{2}{|c|}{$\begin{array}{l}\chi^{2}=692.29 ; d f=4 ; \rho<001 \text { Cramer's } \\
V=0.25\end{array}$} & $\begin{array}{c}\text { Non-process } \\
\text { noun } \\
{[\text {-PROCESs }]} \\
{[\text {-VERBAL }]}\end{array}$ & $\begin{array}{c}\text { Non-verbal process } \\
\text { noun } \\
{[+ \text { PROCESs }]} \\
{[\text {-VERBAL }]}\end{array}$ & $\begin{array}{c}\text { Verbal process } \\
\text { noun } \\
\text { [+PROCESs }] \\
{[+ \text { VERBAL }]}\end{array}$ \\
\hline \multirow{3}{*}{ [zài NP lì] } & Observed N & 709 & 29 & 37 \\
\hline & Expected N & 567.42 & 70.75 & 136.82 \\
\hline & Residual & 5.94 & -4.96 & -8.53 \\
\hline \multirow[t]{3}{*}{ [zài NP lì] } & Observed N & 1133 & 2 & 6 \\
\hline & Expected N & 835.39 & 104.17 & 201.43 \\
\hline & Residual & 10.29 & -10.01 & -13.77 \\
\hline \multirow[t]{3}{*}{ [zài NP zhōng] } & Observed $\mathrm{N}$ & 3946 & 693 & 1357 \\
\hline & Expected N & 4403.1884 & 549.07 & 1061.74 \\
\hline & Residual & -6.61 & 6.14 & 9.06 \\
\hline
\end{tabular}

relationship. The particle $l \grave{l}$ is less likely to co-occur with nouns denoting a process (e.g., qìngdiăn 'festival' [non-verbal process noun] and biànhuà 'change' [verbal process noun]) but instead tends to co-occur more often with less dynamic nouns. This is consistent with our earlier observation regarding the MDCA that few process nouns were observed in the top 20 collexeme list of the li construction. Therefore, our data suggest that the more dynamic a LM is, the less likely it is to co-occur with lí.

As for [zài NP zhōng], it shows a complementary pattern to lǐ. It tends to cooccur with more dynamic process nouns. Moreover, the higher positive residuals of zhōng with verbal process nouns also suggest that the more dynamic a LM is, the more likely it is to co-occur with zhong. This is consistent with what we have observed for the top 20 collexeme list of the zhong construction (cf. Section 4.1.2).

Finally, [zài NP nèi] shows a positive correlation with non-process nouns and repels process nouns. This pattern is similar to $l i$, which suggests that DYNAMICITY may not be distinctive in differentiating nèi and $l \grave{l}$. However, if we connect this result to our analyses of the previous semantic features (i.e., CONCRETENESS and TIME-RELATEDNESS), it is clear that their preference for non-process nouns comes from rather different semantic groups. Our analysis of TIME-RELATEDNESs suggests that the non-process nouns associated with nè may mostly come from timerelated nouns (i.e., time units and time durations) while lǐ prefers mostly time duration nouns; our analysis of CONCRETENESS suggests that the non-process nouns associated with lì may mostly come from concrete nouns while nèi does not show a preference for concrete nouns. All these nouns fall into the category of non-process nouns in terms of their DYNAMICITY. 
In summary, the general preferences of the three constructions in relation to DYNAMICITY are: (1) Both $l \grave{l}$ and nèi constructions tend to co-occur with nonprocess nouns, which may come from very different semantic groups, and (2) zhōng shows a strong preference for dynamic process nouns.

\section{Conceptualizing containment}

Our two corpus-based quantitative analyses have yielded consistent results for the semantic preferences of LMs among the three CONTAINMENT SPCs. The inductive approach of the MDCA provided a general account of the semantic commonalities of the distinctive collexemes of each construction based on the top 20 LM collexemes ranked by their collostrength (i.e., distinctiveness values). The deductive approach of post-hoc semantic analyses further tested the importance and appropriateness of relevant semantic features discussed in the previous literature more holistically.

Generally speaking, for the li construction, the MDCA suggests a higher degree of semantic heterogeneity in the top collexemes of $l i$. Our second analysis further adds that $l i$ correlates with more diverse semantic features, including ${ }_{3} \mathrm{D}$ concrete nouns, time durations, and non-process nouns. Furthermore, $l i$ is the only particle whose top collexemes in the MDCA include more concrete LMs. This is consistent with the positive association between $l i$ and ${ }_{3} \mathrm{D}$ concrete nouns in our second analysis. The presence of few process nouns in the top 20 collexeme list of $l_{l}$ from the MDCA is consistent with the strong repulsions between $l^{r}$ and process nouns (both verbal and non-verbal) observed in our second analysis. For the nèi construction, the MDCA shows that it mostly attracts temporal nouns, and this result is supported by our second analysis. TIME-RELATEDNESS turns out to be the most distinctive semantic feature to distinguish nèi from the other two particles. For the zhong construction, the MDCA shows that it attracts mostly process nouns. The second analysis further suggests that this construction tends to co-occur with process nouns of high dynamicity. The more dynamic the LM, the more likely it is to co-occur with zhōng.

CONTAINMENT has been a widely discussed image schema in research on cognitive linguistics (Lakoff \& Johnson 1980, Johnson 1987, Langacker 1991a, Lakoff 1993, Johnson \& Lakoff 2002, Dewell 2005, Mandler \& Cánovas 2014). Gibbs (2005:91) defines image schemas as "more abstract than ordinary visual mental images and consist[ing] of dynamic spatial patterns that underlie the spatial relations and movement found in actual concrete images." In other words, an image schema is an abstract template grounded in our bodily experiences and interactions with concrete objects. For example, every morning, we pour milk 'into' a 
glass, grab a piece of bread 'in' hand and then put it 'into' our mouth. These experiences work together to shape the image schema of CONTAINMENT. Typical experiences with CONTAINMENT are always "spatially bounded" and most likely involve a three-dimensional enclosure (e.g., in a house), consisting of "a boundary distinguishing an interior from an exterior" (Johnson 1987).

Based on the corpus analysis, this study has demonstrated how the image schema of CONTAINMENT is used to encode both spatial and non-spatial relations with a range of entities as LMs. In addition, these corpus-based distributional patterns of the distinctive collexemes have enabled us to identify the important semantic features of the respective constructions. In this section, we connect our findings to the conceptualization of CONTAINMENT and argue that these distinctive collexeme variations may give us a clue as to how CONTAINMENT is utilized as a cognitive mechanism to conceptualize non-spatial relations with diverse abstract concepts (i.e., CONCRETENESS, TIME-RELATEDNESS, and DYNAMICITY) (Talmy 1983, Johnson 1987, Lakoff 1987). The preference of each SPC may reflect different types of metaphorical extension of this CONTAINMENT schema.

CONTAINMENT can be defined as "a trajector located within a landmark which has three structural elements, an interior, a boundary, and an exterior" (Evans \& Tyler 2004: 167), and a canonical LM is often a three-dimensional bounded entity (Johnson 1987, Tyler \& Evans 2003, Evans \& Tyler 2004). In this section, we start with how a prototypical CONTAINMENT is instantiated in the three SPCs and then discuss other more extended uses in relation to the SPC alternations.

\subsection{Containment with concrete entities}

Of the three CONTAINMENT particles, $l i$ is the only one that showed a strong association with three-dimensional concrete LMs in our post-hoc semantic analysis (cf. Table 10), which is likely to be a prototypical use of the CONTAINMENT image schema.

(5) a. Wǒ zài mígōng lî jiàn dào le liăng zuò shíbēi.

I ZAI maze LI see to PFV two CL stele 'I saw two steles in the maze.'

b. Zài yí piàn báimángmáng de xuědì lǐ wǒ dēng shàng gǔlăo de ZAI one CL gleaming.white DE snowfield LI I climb up ancient DE hèchéng.

Hecheng

'In the white snowfield, I climbed up the ancient Hecheng Mountain.'

The example in (5a) describes a spatial relation of a TR contained in a threedimensional concrete LM, mígong 'maze', which is argued to be a canonical LM 
for CONTAINMENT. When the LM is two-dimensional and is used with the $l_{l}$ construction, it would be conceptualized metaphorically as a three-dimensional bounded LM. For example, xuédì 'snow field' in (5b) would be interpreted as a structure of depth (through which it is perhaps a struggle to walk).

In addition, our MDCA also shows that the li construction may co-occur with LMs of a wide range of semantic types (e.g., time-related nouns and process nouns). This suggests that the CONTAINMENT topological relation covers a wide range of meanings within the $l i$ construction. Therefore, we suggest that of the three particles, $l_{l}$ is probably the unmarked form for CONTAINMENT in Chinese, instantiating more prototypical uses of CONTAINMENT in its concrete sense. Compared to the other two particles, if $l i$ is the unmarked form for the relation of CONTAINMENT, then it probably can be used in more diverse abstract domains, and its interpretation will be more neutral than the other two particles. Our analyses of the other two particles provide support for this hypothesis.

\subsection{Containment with temporal entities}

Our post-hoc semantic analysis has shown that both lǐ and nèi often co-occur with LMs which encode temporal concepts. In particular, while nèi is associated with LMs which encode both time unit and time duration, $l i$ is more strongly associated with time duration.

A closer look at the concordance lines of these two constructions suggest that the two particles highlight different aspects of the temporal property. The nè construction highlights the temporal boundary marked by the LM (i.e., the time unit/duration) and often signals the crossing of a temporal boundary (a so-called "threshold reading" where, for example, the boundary of the containment is a deadline for a preplanned objective), as shown in (6a) and (6b). After a brief survey of the concordance lines from the Sinica Corpus, we found that most nèi constructions do indeed have a threshold reading. Use of the nèi construction often also implies an implicit objective, as well as the temporal deadline for achieving it. For example, in (6a), the implicit objective is to lose 50-70 kg. In (6b), the implicit objective is to develop the country into a modern one. The temporal LMs in both examples are the expected deadlines.

(6) a. Tã jìhuà zài yì nián nèi wánchéng shòu shēn xīwàng jiăn diào 50 zhì 70 he plan ZAI one year NEI finish thin body wish lose to 50 to 70 gōngjīn.

kilogram

'He planned to lose weight in one year and hoped to lose 50 to 70 kilograms.' 
b. Xīnjiāpō zài hěn duăn qíjiān nèi chéngwéi yíge guójìhuà de Singapore ZAI very short period NEI become one internationalized DE xiàndài dūshì. modern city

'Singapore became an internationalized modern city within a very short period of time.'

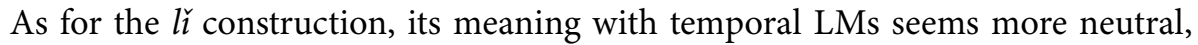
which aligns with our earlier hypothesis that this particle may be a less marked form for encoding CONTAINMENT. Unlike nèi, the activities modified by [zài NP li] often do not imply a preplanned objective or an expected deadline. In ( $7 \mathrm{a})$, wúsuǒshishì 'doing nothing' does not motivate a reading of being a preplanned goal; likewise, in ( $7 \mathrm{~b})$, losing weight is not preplanned by the subject, but is a side effect of kidney dialysis.
a. Zài dàiyè
de zhè duàn qíjiān lǐ zhěng tiān gèng shì

ZAI unemployed DE this CL period LI all day more COP

wúsuǒshìshì.

doing.nothing

'In between jobs, he did nothing all day long.'

b. Yǒushí wúpèiwén hái děi kào xǐshèn dù rì zài bú guò liăng sometimes Wupeiwen still need rely dialysis pass day ZAI NEG more two sān ge yuè de shíjiān lǐ wúpèiwén shòu le zúzú shí duō three CL month DE time LI Wupeiwen thin PFV no.less ten more gōngjīn.

kilogram

'Sometimes, Wupeiwen even had to rely on the dialysis for living. In no more than two or three months, Wu had lost even at leastıo kilograms.'

Therefore, our analysis suggests that in Chinese the image schema of CONTAINMENT is used to conceptualize temporal relations through two SPCs, [zài NP lì] and [zài NP nèi]. In these metaphorically extended uses with temporal LMs, the li construction seems more unmarked, showing little particularized reading on the LM (e.g., threshold and preplanned objective). However, the metaphorical use of the nèi construction with temporal LMs may motivate more particularized meanings - the reading of a preplanned objective with an expected deadline, for example. 


\subsection{Containment with dynamic entities}

In addition to the temporal domain, our analyses have also shown that the image schema of CONTAINMENT can also be used with LMs that are very abstract or even encode dynamic activities. More specifically, our results show that the zhong construction is strongly associated with LMs encoding high-dynamicity abstract concepts (cf. Table 12). This tendency is also shown clearly by its top 20 distinctive collexemes, most of which are process nouns denoting dynamic activities.

As for the other two constructions, our semantic analyses suggest that the $l i$ and nèi constructions are more strongly associated with low-dynamicity abstract concepts (e.g., non-process nouns in Table 12). In addition, our analysis of TIMERELATEDNESS suggests that the non-process nouns associated with nèi mostly come from LMs encoding time units and time durations, while li prefers mostly time duration nouns. Also, the analysis of CONCRETENESs suggests that the nonprocess nouns associated with $l_{i}$ are mostly concrete nouns, while nèi does not show a preference for concrete nouns.

Several implications can be drawn from these co-occurrence patterns. First, in Chinese the CONTAINMENT image schema is used to conceptualize abstract concepts of differing degrees of dynamicity, ranging from low-dynamicity static concepts to dynamic processes. Secondly, the relationship between static abstract LMs and the $l_{l}$ construction may also be aligned with our hypothesis that $l_{l}$ is the unmarked form for CONTAINMENT in Chinese. Taking a low-dynamicity concept as the LM of CONTAINMENT, a neutral reading is to conceptualize the concept as a bounded container metaphorically, without a particular specification of the relative positions of the TR in the LM. As suggested earlier, the li construction in Chinese is more strongly associated with prototypical bounded concrete entities as the LM. We posit that a metaphorical extension of CONTAINMENT to abstract concepts may therefore take the li construction as the choice for a neutral unmarked reading. A review of concordance lines suggests that when li demonstrates a metaphorical use of CONTAINMENT with an abstract concept as the LM, it is less likely to invite a particularized or pragmatically-marked reading (e.g., an aspectual reading of the LMs), as in (8).

(8) Zài zhèyàng nánxìng bàquán de fēnwéi lǐ nǔxìng chéngwéi nánxìng ZAI such male hegemony DE atmosphere LI female become male fùyōng de gōngjùxìng jiăosè.

affiliated DE instrumental role

'In the atmosphere of male hegemony, females turn out to have an affiliated instrumental role to males' 
Of particular interest is the relationship between zhong and high-dynamicity LMs. A survey of the concordance lines from the Sinica Corpus indicates that most zhong constructions motivate an "aspectual" reading of the LM, where the internal temporal structure of the activities encoded by the LM is more salient. This may be partly attributed to the fact that high-dynamicity concepts often refer to dynamic and/or durative activities consisting of internal stages. For example, in (9a), the LM, jizhěhui 'press conference', is conceptualized as a process with several internal temporal stages, and at one particular stage, Mr. Chiu made the statement. The same interpretation can be seen in (9b).

a. Qiū Jinyì zài jìzhěhuì zhōng zhǐ chū

Qiū Jinyì ZAI press.conference ZHONG point out

guótǒnghuì yóu lǐ zǒngtǒng dēnghuī xiānshēng jiānrèn

national.unification.council by Li president Denghui mister adjunct

zhǔrènwěiyuán.

chairman

'In the press conference, Qiu Jinyi pointed out that President Li would hold a concurrent position as the adjunct chairman in National Unification Council.'

b. Kǒushuǐ huì zài zhìliáo zhōng jiù hěnkuài de jiănshăo biàndé saliva will ZAI treatment ZHONG just rapid DE decrease become chóunián.

stringy

'Saliva will decrease rapidly and become stringy during the treatment.'

Therefore, our analyses suggest that the image schema of CONTAINMENT can be used with LMs that denote not only low-dynamicity concepts as LM, but also high-dynamicity event-like concepts. The former often co-occurs with the li construction, which demonstrates a more neutral reading of the extended uses, with the latter often co-occurring with the zhong construction, which showcases a more particularized reading of the metaphorical extension (e.g., an imperfective aspectual reading of the $\mathrm{LM}$ ).

\section{Conclusion}

This study has investigated three Chinese SPCs [zài NP lǐ/nèi/zhōng], which encode the concept of CONTAINMENT. Differing from the qualitative analyses of previous work, this study adopted a corpus-based approach and examined the relationship between the space particles and their co-occurring LMs through 
two quantitative analyses - multiple distinctive collexeme analysis and post-hoc semantic analysis.

Our results show that each construction has its own semantic preference for the LMs. These differences reflect how Chinese speakers utilize the image schema of CONTAINMENT to conceptualize spatial relationships with a range of abstract concepts. The $l \check{l}$ construction, while it tends to attract more diverse types of LM, shows a stronger connection to a prototypical "container" - that is, a three-dimensional bounded concrete entity - than the other two particles. It is posited that the li construction may be a more unmarked form to encode coNTAINMENT. The nèi construction shows a strong preference for LMs denoting temporal concepts. This extended use of CONTAINMENT with temporal LMs often implies a preplanned objective with the LM as an intended deadline for achieving the goal. Finally, the zhong construction shows a strong connection to LMs denoting events of higher dynamicity. This metaphorical use of CONTAINMENT with dynamic abstract entities as LMs often comes with a marked specificity, motivating an aspectual reading of the LM.

We speculate that variation in the CONTAINMENT conceptualizations of the three SPCs may be summarized by three different mental representations of the image schema, as illustrated in Figure 2, which is based on Yang's (2008) proposal.

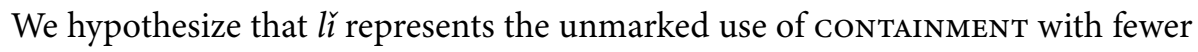
particularized semantic features attached to the LM (e.g., profiling neither the boundary nor the internal structure of the LM). However, the other two particles may instantiate more marked uses of the image schema with more particularized profiles in the mental representation. CONTAINMENT encoded by nèi may highlight the importance of the boundary specified by the LM, thus often motivating additional readings of specificity (e.g., the boundary as the threshold or deadline). CONTAINMENT encoded by zhong may highlight more of the internal structure of the LM (i.e., the aspectual properties) and may often profile a particular stage of the LM for an imperfective or aspectual reading of the LM.

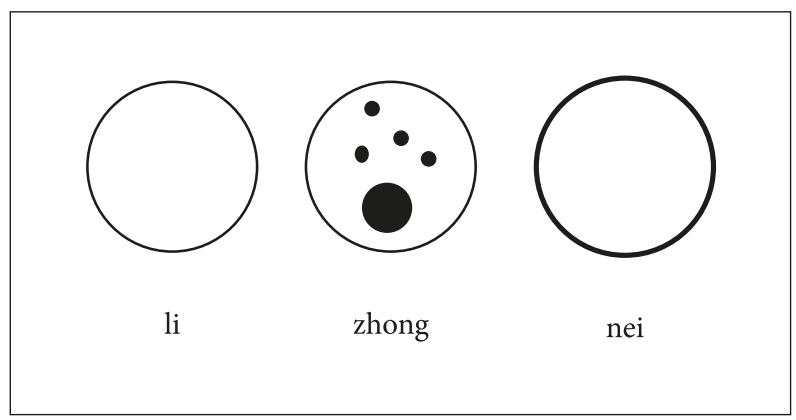

Figure 2. Schematic mental representations of the three spatial particles 
This study has several limitations. First, the SPC was defined as [zài NP lí/ nèi/zhōng]. It remains unclear whether the presence of the particle zài might also play a role in the semantic distribution of the LM. Previous studies did not make a distinction with respect to the occurrence of zài (Xing 1996, Deng 2006, Yang 2008, Zhang \& Liu 2008). The reason for including zài as a necessary component for the SPC in this study was to ensure common syntactic ground for the semantic comparison of these particles. [NP lì/nèi/zhōng], without zài, occurs in more diverse syntactic positions, with both nominal and adverbial uses, which may introduce more confounding factors into the semantic analyses of these particles (e.g., whether the NP and the space particle should be treated as one lexical item). Another limitation is the limited scope of the SPCs. The present study only analyzed the co-occurrence of the particles and the LMs within the syntactic scope of the SPCs, but did not analyze the main predicate or the proposition modified by them. In Section 5, we have sampled a few concordance lines to discuss the possible enriched meanings arising from the extended uses of the CONTAINMENT image schema with other abstract LMs. Future studies may need to examine more closely the propositions that co-occur with these constructions in order to provide a more comprehensive account of semantic specificity in the metaphorical extensions of these space particles. Finally, as these three particles come from different etymological sources (Deng 2006), future study may further examine to what extent the distinctive semantic properties demonstrated by each space particle may be connected to their etymology in the process of their grammaticalization.

\section{Acknowledgements}

This research was supported by funds from Taiwan Ministry of Science and Technology (104-2410-H-003-134) and National Taiwan Normal University (T10607000102), granted to the second author. This work was based on the master thesis project of the first author completed under the supervision of the second author. The authors would like to thank the committee members for their constructive feedback. We are also grateful to the two anonymous reviewers and the editors for their very helpful suggestions on the previous versions of the manuscript. 


\section{List of abbreviations for inter-linear glossing}

\author{
CL classifier \\ COP copular \\ $\mathrm{DE}$ associative marker $d e$
}

\author{
IPFV imperfective \\ NEG negation, negative \\ PFV perfective
}

\section{References}

Boers, Frank. 1996. Spatial Prepositions and Metaphor: A Cognitive Semantic Journey Along the Up-Down and the Front-Back Dimensions. Tübingen, Germany: Gunter Narr Verlag.

Boroditsky, Lera. 200o. Metaphoric structuring: Understanding time through spatial metaphors. Cognition 75.1:1-28. https://doi.org/10.1016/So010-0277(99)00073-6

Croft, William. 2001. Radical Construction Grammar: Syntactic Theory in Typological Perspective. Oxford, UK: Oxford University Press. https://doi.org/10.1093/acprof:oso/9780198299554.001.0001

Croft, William, and Alan Cruse. 2004. Cognitive Linguistics. Cambridge, UK: Cambridge University Press. https://doi.org/10.1017/CBO9780511803864

Deng, Fang. 2006. Fangwei Jiegou "X Zhong/Li/Nei” Bijiao Yanjiu [A Contrastive Study of the Locative Structures "X Zhong/Li/Nei"]. MA thesis, Jinan University, Canton.

Dewell, Robert B. 2005. Dynamic patterns of containment. From Perception to Meaning: Image Schemas in Cognitive Linguistics, ed. by Beate Hampe and Joseph E. Grady, 369-393. Berlin, Germany: Mouton de Gruyter. https://doi.org/10.1515/9783110197532.5.369

Evans, Vyvyan, and Andrea Tyler. 2004. Spatial experience, lexical structure and motivation: The case of in. Studies in Linguistic Motivation, ed. by Günter Radden and Klaus-Uwe Panther, 157-192. Berlin, Germany: Mouton de Gruyter.

Firth, John Rupert. 1957. A synopsis of linguistic theory, 1930-55. Studies in Linguistic Analysis, ed. by John Rupert Firth, 1-31. Oxford, UK: Basil Blackwell.

Gibbs, Jr. Raymond W. 2005. Embodiment and Cognitive Science. Cambridge, UK: Cambridge University Press. https://doi.org/10.1017/CBO9780511805844

Gilquin, Gaëtanelle. 2006. The verb slot in causative constructions: Finding the best fit. Constructions S1.3:1-46.

Goldberg, Adele E. 2006. Constructions at Work: The Nature of Generalization in Language. Oxford, UK: Oxford University Press.

Gries, Stefan Th. 2009. Quantitative Corpus Linguistics with R: A Practical Introduction. New York, NY: Routledge. https://doi.org/10.1515/9783110216042

Gries, Stefan Th., and Anatol Stefanowitsch. 2004a. Co-varying collexemes in the into-causative. Language, Culture, and Mind, ed. by Michel Achard and Suzanne Kemmer, 225-236. Stanford, CA: CSLI.

Gries, Stefan Th., and Anatol Stefanowitsch. 2004b. Extending collostructional analysis: A corpus-based perspective on 'alternations'. International Journal of Corpus Linguistics 9.1:97-129. https://doi.org/10.1075/ijcl.9.1.06gri

Gries, Stefan Th., and Nick C. Ellis. 2015. Statistical measures for usage-based linguistics. Language Learning 65.S1:228-255. https://doi.org/10.1111/lang.12119 
Huang, Chu-Ren, and Keh-jiann Chen. 2010. Academia sinica balanced corpus of modern Chinese 4.o. Academia Sinica. Retrieved January 13, 2016, from http://asbc.iis.sinica.edu .tw/

Hunston, Susan, and Gill Francis. 200o. Pattern Grammar: A Corpus-Driven Approach to the Lexical Grammar of English. Amsterdam, Netherlands: John Benjamins. https://doi.org/10.1075/scl.4

Jackendoff, Ray. 1983. Semantics and Cognition. Cambridge, MA: MIT Press.

Janda, Laura A. 2013. Quantitative methods in cognitive linguistics: An introduction. Cognitive Linguistics: The Quantitative Turn, ed. by Laura A. Janda, 1-32. Berlin: Walter de Gruyter. https://doi.org/10.1515/9783110335255.1

Johnson, Mark. 1987. The Body in the Mind: The Bodily Basis of Meaning, Imagination, and Reason. Chicago, IL: University of Chicago Press.

Johnson, Mark, and George Lakoff. 2002. Why cognitive linguistics requires embodied realism. Cognitive Linguistics 13.3:245-263. https://doi.org/10.1515/cogl.2002.016

Lakoff, George. 1987. Women, Fire, and Dangerous Things: What Categories Reveal about the Mind. Chicago, IL: University of Chicago Press. https://doi.org/10.7208/chicago/9780226471013.001.0001

Lakoff, George. 1993. The contemporary theory of metaphor. Metaphor and Thought, ed. by Andrew Ortony, 202-251. Cambridge, UK: Cambridge University Press. https://doi.org/10.1017/CBO9781139173865.013

Lakoff, George, and Mark Johnson. 1980. Metaphors We Live By. Chicago, IL: University of Chicago Press.

Langacker, Ronald W. 1991a. Concept, Image, and Symbol: The Cognitive Basis of Grammar. Berlin: Mouton de Gruyter.

Langacker, Ronald W. 1991b. Foundations of Cognitive Grammar: Descriptive Application. Stanford, CA: Stanford University Press.

Langacker, Ronald W. 1997. Constituency, dependency, and conceptual grouping. Cognitive Linguistics 8.1:1-32. https://doi.org/10.1515/cogl.1997.8.1.1

Levinson, Stephen, Sérgio Meira, and The Language and Cognition Group. 2003. 'Natural concepts' in the spatial topological domain - adpositional meanings in crosslinguistic perspective: An exercise in semantic typology. Language 79.3:485-516. https://doi.org/10.1353/lan.2003.0174

Lindstromberg, Seth. 2010. English Prepositions Explained: Revised Edition. Amsterdam, Netherlands: John Benjamins. https://doi.org/10.1075/z.157

Liu, Dilin. 2010. Is it a chief, main, major, primary, or principal concern? A corpus-based behavioral profile study of the near-synonyms. International Journal of Corpus Linguistics 15.1:56-87. https://doi.org/10.1075/ijcl.15.1.03liu

Mandler, Jean Matter, and Cristóbal Pagán Cánovas. 2014. On defining image schemas. Language and Cognition 6.4:510-532. https://doi.org/10.1017/langcog.2014.14

Menzel, Peter. 1975. Semantics and Syntax in Complementation. Hague, Netherlands: Mouton.

Miller, George Armitage, and Philip N. Johnson-Laird. 1976. Language and Perception. Cambridge, MA: Belknap Press. https://doi.org/10.4159/harvard.9780674421288

Ono, Tsuyoshi, and Sandra A. Thompson. 1996. Interaction and syntax in the structure of conversational discourse: Collaboration, overlap, and syntactic dissociation. Computational and Conversational Discourse: Burning Issues - An Interdisciplinary Account, ed. by Eduard H. Hovy and Donia R. Scott, 67-96. Berlin: Springer. https://doi.org/10.1007/978-3-662-03293-0_3 
Pollio, Howard R., Lance B. Fagan, Thomas R. Graves, and Priscilla Levasseur. 2005. The semantics of space: Experiential and linguistic aspects of selected English spatial terms. Journal of Psycholinguistic Research 34.2:133-152. https://doi.org/10.1007/s10936-005-3635-4

Sandra, Dominiek, and Sally Rice. 1995. Network analyses of prepositional meaning: Mirroring whose mind - the linguist's or the language user's? Cognitive Linguistics 6.1:89-130. https://doi.org/10.1515/cogl.1995.6.1.89

Sinclair, John. 1991. Corpus, Concordance, Collocation. Oxford, UK: Oxford University Press.

Stefanowitsch, Anatol, and Stefan Th. Gries. 2003. Collostructions: Investigating the interaction of words and constructions. International Journal of Corpus Linguistics 8.2:209-243. https://doi.org/10.1075/ijcl.8.2.03ste

Stefanowitsch, Anatol, and Stefan Th. Gries. 2005. Covarying Collexemes. Corpus Linguistics and Linguistic Theory 1.1:1-43. https://doi.org/10.1515/cllt.2005.1.1.1

Svorou, Soteria. 1994. The Grammar of Space. Amsterdam, Netherlands: John Benjamins. https://doi.org/10.1075/tsl.25

Talmy, Leonard. 1983. How language structures space. Spatial Orientation: Theory, Research, and Application, ed. by Herbert L. Pick, Jr. and Linda P. Acredolo, 225-282. New York, NY: Plenum Press. https://doi.org/10.1007/978-1-4615-9325-6_11

Thompson, Sandra A., and Elizabeth Couper-Kuhlen. 2005. The clause as a locus of grammar and interaction. Discourse Studies 7.4-5:481-505. https://doi.org/10.1177/1461445605054403

Tomasello, Michael. 2003. Constructing a Language: A Usage-Based Theory of Language Acquisition. Cambridge, MA: Harvard University Press.

Tyler, Andrea, and Vyvyan Evans. 2001. Reconsidering prepositional polysemy networks: The case of over. Language 77.4:724-765. https://doi.org/10.1353/lan.2001.0250

Tyler, Andrea, and Vyvyan Evans. 2003. The Semantics of English Prepositions: Spatial Scenes, Embodied Meaning, and Cognition. Cambridge, UK: Cambridge University Press. https://doi.org/10.1017/CBO9780511486517

Xing, Fu Yi. 1996. Fangwei jiegou "X li" yu "X zhong" [The locative structure "X li" and "X zhong"]. Shijie Hanyu Jiaoxue 4:4-15.

Yang, Hui. 2008. Ronchi fangweici li zei zhong wai de kongjian yiyi [The spatial meaning of words of containers li, nei, zhong, wai]. Shichuan Jiaoyu Xuebao 24.12:74-76.

Zaenen, Annie, Jean Carletta, Gregory Garretson, Joan Bresnan, Andrew Koontz-Garboden, Tatiana Nikitina, M. Catherine O'Connor, and Tom Wasow. 2004. Animacy encoding in English: Why and how. Proceedings of the 2004 ACL Workshop on Discourse Annotation, ed. by Bonnie Webber and Donna Byron, 118-125. Stroudsburg, PA: Association for Computational Linguistics. https://doi.org/10.3115/1608938.1608954

Zeng, Chuan-lu. 2005. "Li, zhong, nei, wai" fangwei yinyu de renzhi fenxi [A cognitive analysis of the orientational metaphors in "li, zhong, nei, wai"]. Guizhou Daxue Xuebao (Shehui Kexue Ban) 1:104-107.

Zhang, Jin Sheng, and Yun Hung Liu. 2008. "Li” "zhong” "nei" kongjian yiyi de renzhi yuyanxue kaocha [A cognitive linguistic analysis of the spatial meanings of $l i$, zhong, and nei]. Jiefangjun Waiguoyu Xueyuan Xuebao 31.3:7-12. 
Address for correspondence

Alvin Cheng-Hsien Chen

Department of English

National Taiwan Normal University

Taipei, TAIWAN

alvinchen@ntnu.edu.tw

\section{Co-author information}

\section{Hung-Kuan Su}

Department of English

National Taiwan Normal University

Taipei, TAIWAN

jacksugood@gmail.com

\section{Publication history}

Date received: 19 September 2018

Date revised: 6 November 2018

Date accepted: 2 July 2019 